\title{
Reflections on the Management of College Student during an Outbreak of 2019 Novel Coronavirus Diseases (COVID-19)
}

\author{
Shaoqin Liu, Yuzhuo Liu, Zhe Sun \\ Heilongjiang Bayi Agricultural University, Daqing, China \\ Email: 251550931@qq.com
}

How to cite this paper: Liu, S. Q., Liu, Y. Z., \& Sun, Z. (2020). Reflections on the Management of College Student during an Outbreak of 2019 Novel Coronavirus Diseases (COVID-19). Open Journal of Social Sciences, $8,447-454$.

https://doi.org/10.4236/jss.2020.86034

Received: June 1, 2020

Accepted: June 25, 2020

Published: June 28, 2020

Copyright $\odot 2020$ by author(s) and Scientific Research Publishing Inc. This work is licensed under the Creative Commons Attribution International License (CC BY 4.0).

http://creativecommons.org/licenses/by/4.0/

\section{(c) (i) Open Access}

\begin{abstract}
Since December, Wuhan, the capital city of central China's Hubei Province, has continuously found many cases of viral pneumonia, and all of them have been diagnosed with pneumonia caused by novel coronavirus. And the virus is transmissible between humans. As of March 1, there have been 2803 fatalities due to novel coronavirus infection across the country. Xi Jinping, general secretary of the Communist Party of China Central Committee, gave important instructions to the epidemic and resolutely curbed the spread of the virus. Measures such as traffic control, delayed start of construction, and blockade of building areas were implemented in localities. Elementary and secondary schools and colleges throughout the country suspended the open of school and conducted online teaching. Under the circumstances of the postponement of school semesters and the inability to go out due to the epidemic, college students are facing significant psychological pressure, academic pressure and employment pressure, and some students have various problems such as panic, anxiety and insomnia. This article proposes a series of new management measures and solutions to the various situations of students during the epidemic to ease its impact on college students under the condition that it does not affect the control of the virus.
\end{abstract}

\section{Keywords}

Novel Coronavirus, College Management, Innovation

\section{Introduction}

The novel coronavirus was discovered due to a viral pneumonia case in Wuhan in December 2019, and was named by the World Health Organization on Janu- 
ary 12,2020 . Since the epidemic was discovered, in order to curb the spread of the epidemic, the Ministry of Education has issued relevant policies. Elementary and secondary schools, colleges around the country have delayed the spring semesters, adopted closed management and students have strictly prohibited from returning to school in advance. Due to the impact of the epidemic, the postponement of job fairs, the suspension of student internship practice, and the cancellation of offline concentration activities, which makes the management of students in universities face great challenges. But at the same time, they are also keeping the pace of using the Internet platforms to carry out different types of online education. And it has achieved remarkable results. In view of the difficulties faced by the management of college students, colleges and universities should innovate management models, explore management methods, and resolutely help the country to win the battle against epidemic and maintain students' mental health.

\section{Contents of Student Management in Colleges and Universities}

On December 16, 2016, the Ministry of Education of the People's Republic of China promulgated the newly revised "Regulations on the Management of Students in Ordinary Colleges and Universities". The promulgation of this regulation has played an important role in the implementation and demonstration of student management in colleges and universities. And it refers to the daily management of students from enrollment to graduation, which involving students' daily management, school membership management, construction of campus culture and party and group class, rewards and punishment cancellation, mental health education, career planning and employment guidance, student complains and many other aspects. In terms of the current form, we often say that student management work refers to the cultivation of students' innovative and entrepreneurial spirit, voluntary service awareness, hands-on practical skills, and social practical ability. And the ultimate goal of college students' work is to comprehensively cultivate high-caliber personnel. The concept of university student work is to focus on the construction of party groups: enhancing the status of ideological and political education comprehensively which guided by the atmosphere of academy and dormitory; creating a good learning atmosphere and dormitory environment with the construction of campus culture; improving the comprehensive quality of students based on the school system; advancing the echelon of the student work team relied on social practice and volunteer service (Xu, 2019a); cultivating students' service awareness and labor capacity depended on career planning and employment guidance; improving student's employability which taking brand activities and technological innovations as a platform. The concept of student work is the basis for colleges to carry out student management work, which has the role of guiding and regulating students' daily behaviors. 


\section{The Problems Faced in the Work of College Students during the COVID-19}

\subsection{Hindrances of Offline Education}

As we all know, the pandemic has reached a crucial juncture now, and colleges and universities have successively issued plans for the start of work for the spring semester of 2020. Postponement of school semesters has become an inevitable trend. After the start of the school, the gathering activities for students will also be greatly reduced. All colleges and universities strictly control all kinds of gathering activities in accordance with the principle of "not necessary, not held". And the control of public venues and public facilities in universities will also be very strict. And it has hit the development of offline student education and management. The management of college students has long been focused on offline centralized education and management, especially on campus culture construction, party and class construction, social practice, volunteer services, student employment, etc., which are closely dependent on offline activities.

\subsection{Severe Challenges of Network Ideology Education}

"Ideology, as an important part of social thought, once formed, its maintenance process is also the process of ideological education of the ruling party to the masses" (Ao, 2011). In the era of rapid development of new media technology, the Internet as the main platform and media for information dissemination and flow, which is characterized by multiformity, diversity and complexity. College students are also a new force of the Internet platform, so the dissemination of Internet information has had a significant impact on college students' outlook on life, world view and values. As the widespread of Internet information dissemination, a large amount of false and inductive information has entered the field of vision of college students. In the critical period of the national war epidemic, there are also some lawbreakers and hostile forces that create public opinion through the Internet to mislead students, and spare no effort to grab the right to speak online. Therefore, the Internet has increasingly become a battlefield for ideology and public opinion struggles. Against the backdrop of various hostile forces and lawbreakers competing for discourse, colleges and universities, as the main positions for educating people, are under tremendous pressure. Maintaining the security of the network ideology of colleges and universities is a major issue that whether the builders and successors of the socialist cause with Chinese characteristics in the new era could be up to the task, whether young college students could choose the right values and whether they would support the Communist Party of China (CPC) (Xu, 2019b).

\subsection{Severe Challenges of Student Psychological Counseling}

Nowadays, mental illness has become an important problem that colleges and universities must to face and solve. College students are generally in a sub-healthy psychological state. During the epidemic period, there is also the outbreak pe- 
riod of college students' metal problems. Most of college students' minds are not fully mature yet, their self-recognition and positioning are unclear, and they lack the ability to distinguish right from wrong. Students and new graduates, who have mental illness, are likely to be negative or panicky due to pressures such as epidemic situations, employment or induction of public opinion. Under the poor psychological state of long-term, students will develop into psychological obstacles or even depression. The management staff of colleges has attached great importance to this. However, due to the epidemic situation is during the winter vacation and other reasons, colleges cannot provide offline one-to-one psychological counseling to students, nor they can find problems through teachers and classmates in a timely and effective manner, which leading to a stalemate in psychological counseling.

\subsection{Increasing Difficulties in Student Daily Management}

For colleges and universities, the daily management of students is their basic work and an important part of ensuring their smooth operation and safety. Now, online education activities bring huge challenges to daily management of students. Whether it is the usual course inspection or daily thought guidance, whether it is the construction of academic atmosphere or the construction of party groups, whether it is policy interpretation or timely and accurate message transmission, there are still many uncertainties factors. As we all know, only when the students are physically and mentally healthy will the family be happy, and then our society will develop in harmony. But now, each counselor teacher needs to face 200 students or more and each student is behind a family. So how to ensure that every students could know the school's relevant regulations of management and prevention, teaching arrangements and be safe, which will be the emphasis and difficulty on our work.

\section{The Innovation of the Working Model during the Epidemic}

\subsection{Using Online Education Instead of Offline Education}

According to the current development trend of the novel coronavirus pandemic, the Ministry of Education requires all colleges and universities to use the online platforms to "suspend classes without stopping teaching" and "suspend classes without stopping learning". It is imperative that universities rely on the Internet platform to implement online education management. Many colleges and universities have also launched online teaching training for teachers and students. Some colleges and universities have developed online teaching plans and used the network to carry out course teaching. At the same time, college student management models are also facing reform and innovation. We need to utilize the Internet platforms with effectiveness, universality, and extensiveness to carry out student management work. Colleges and universities use the intra-school APP, Yiban and other network platforms to receive daily reports of students' 
"health system", and it is easy to monitor student health through big data. By means of the official website, Weibo, WeChat Official Accounts and other platforms, colleges and universities post the "Guide to Prevent Pneumonia Caused by the Novel Coronavirus in Public Places" "Prevention and Protection Handbook Against COVID-19" issued by the Chinese Center for Disease Control, and the school's various rules, knowledge of preventing epidemic, psychological counseling, typical deeds and other content to ensure that students can understand the school's various measures at the first time. Meanwhile, these will help students to enhance awareness of prevention, maintain physical and mental health, and create a good atmosphere of the national anti-epidemic. During the epidemic period, college student managers should seize the opportunity to make full use of the online platforms to give students ideal and belief education courses, mental health education courses, safety education courses, gratitude education courses, employment guidance and career planning courses to guide students to establish the correct "three outlooks" of the epidemic. The counselors even vividly illustrated their responsibilities by means of anti-epidemic articles, online class meetings, and every small things. In the face of unprecedented employment pressure, the government and universities have taken a lot of measures, and the Heilongjiang Provincial Department of Education launched the "Heilongjiang University Employment and Entrepreneurship Service Platform" in October 2019. The platform is now shared data and news with the province's universities and employers. Employers can post employment information after registering on the platform. And after students register, they can submit resumes to their favorite unites. Online job fairs, online resumes, online written exams, and video interviews will be organized by different categories and levels. At last, signing up online to help students find jobs without leaving home. Colleges and universities build online recruitment models of enterprises, students and schools through employment websites and employment platforms, broadening employment platforms, inviting enterprises to be recruited, simplifying the employment process, improving the employment system, and to lessen the influence of the employment of 2020 graduates.

\subsection{Strengthening Public Opinion Guidance and Creating a Good Atmosphere}

University administrators timely and accurately release the epidemic prevention information and work arrangements of the country, the Ministry of Education, schools and colleges. A five-level grid management system of college-institutegrade-class-dormitory, for example Figure 1, is established to monitor the changes of students' thoughts in real time. Through various channels such as official new media platforms and class groups, colleges and universities should educate students with knowledge on epidemic prevention, explain various rules and regulations, answer students' doubts, eliminate panic emotions, guide students to correctly understand the epidemic, and firmly do not believe or spread rumors. No rumors. As the main fronts for the education of Marxist mainstream 


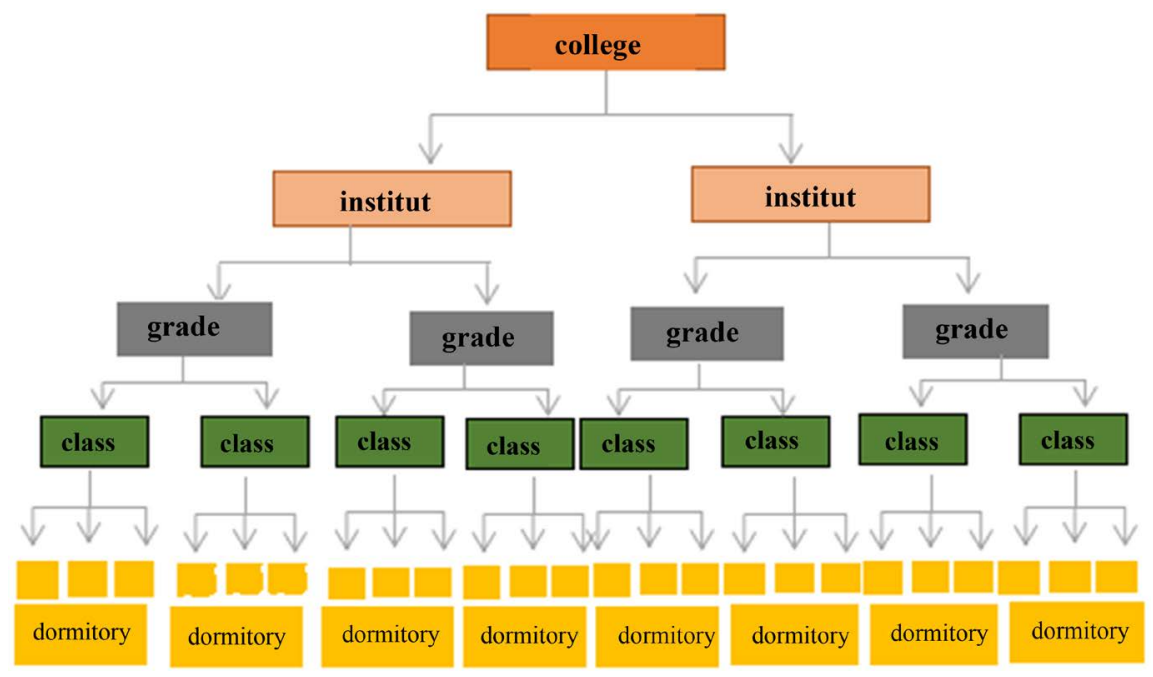

Figure 1. A five-level grid management system of college-institute-grade-class-dormitory.

ideology and the education of socialist ideals and beliefs with Chinese characteristics, universities also should give full play to the leading role of socialist core values by using big data technology (Xuan, 2019). Big data information is more accurate and extensive, which is conducive to the timely monitoring and accurate positioning of public opinion by universities and minimizes the risk of public opinion. Creating a good Internet atmosphere is the focus of the current network ideology work of colleges and universities. And for this to happen, it requires the joint efforts of the country, society and universities. Colleges and universities should be committed to improving self-learning of college students, screening information true and false, strengthening the sense of anti-fraud and the rule of law. And it is also need to guide college students to consciously resist all kinds of false information, and resolutely maintain social harmony.

\subsection{Strengthening Psychological Counseling and Establishing Psychological Prevention and Control Plans}

In the high-incidence period of mental problems, colleges and universities should establish psychological prevention and control plans, integrate families, schools, colleges, grades, classes, and dormitories. It is also needed to understand the psychological status of students in various aspects, and comprehensively care for students with psychological problems, especially get close contact with students' parents during holidays and build an interactive platform for communication. According to statistics, as of the end of $2015,25 \%$ of college students across the country have experienced psychological tests and psychological counseling through the Internet. Apparently up to $58 \%$ of college students are willing to choose the Internet to solve psychological problems (Jiang, 2012), which also reflects from the side that the willingness for online psychological counseling. Colleges and universities should actively open psychological counseling courses, promote psychological epidemic prevention knowledge, and carry out psychological growth activities through online platforms. By using of class QQ groups, 
WeChat groups, Weibo and other network platforms, it could build peer counseling groups. And psychological counseling teachers have targeted conducted mental counseling through QQ groups or other online platforms. There are also crisis hotline for students to relieve their anxiety, handle the grief and help develop healthy life styles and hygiene habits.

\subsection{Adhering to the Approach of Comprehensive Troubleshooting Innovation Management}

The daily management of students is the safeguard of safety and stability of the campus. To do a good job of safety management is to cover all our blind spots continuously for a day without leaving one person. Make sure that administers do know the score, care about special groups, special students, and special problems (Wu \& Zheng, 2010). Colleges and universities hold video grade conferences, class conferences, and student organization meetings through online nailing, cloud class, QQ group and other platforms to inform students of relevant regulations, conduct ideological education, and guide students to arrange a reasonable time. At the same time, students who have difficulties in family should be assisted amid this special period. Students' physical and mental health and ideological dynamics at all times should be monitored to ensure that each student is within the scope of vision. And student management staff should establish a five-level linkage mechanism for parents, students, counselors, class teachers, and teaching teachers to supervise online. Besides, colleges and universities need to keep abreast of the students' psychological dynamics, health status, learning progress, and attendance. In this special period, it is important to strictly implement various management systems and be aware of the students' schedules (Gao \& Ji, 2017). And the establishment of a four-level linkage system of Student Office, Security Office, Logistics, and School Hospital is able to ensure the safety and stability of students.

\section{Conclusion}

With the emergence of novel coronavirus pneumonia epidemic and the spread of it, there are many issues about the postponement of spring semesters and management of administrators. And now, colleges nationwide have rapidly given priority to the innovation of management models, and exploration of the new ways of management (Shen, 2014). The management measures at this stage are to help students better complete the online courses, maintain the security of college network ideology and solve the psychological problems of students. Thereby students could be ensured physical and mental health, and the burden on teachers could be lessened. The new work mode can not only enable students to complete their learning tasks as scheduled, but also enable they understand the relevant knowledge of the epidemic. This would help to ease the psychological pressure to students, reduce the psychological trauma caused by the epidemic to students, and enable students to better protect themselves. It can be seen that in order to respond to the national epidemic management policy and ensure that 
teachers and students in colleges are not affected by the epidemic, it is particularly important to integrate new management concepts and methods into the management of students at ordinary times. This will enable the task of talent training of colleges could be completed on time.

\section{Conflicts of Interest}

The authors declare no conflicts of interest regarding the publication of this paper.

\section{References}

Ao, D. Y. (2011). Research about Socialist Ideology Construction: Hot Issues and Cold Thinking (p. 15). Beijing: People Press.

Gao, M., \& Ji, J. (2017). Research on the Issues of College Student Management in the New Era of the Concept of Ethics and Morality. Education Modernization, 4, 279-280.

Jiang, Q. L. (2012). Construction of Network Mental Health Education System in Universities. Changsha: Central South University.

Shen, H. G. (2014). A Preliminary Study on the Refined Management Model of College Students. Years and Society, No. 3, 197.

Wu, S. Z., \& Zheng, S. Q. (2010). Theory on How Do Counselors Do the Daily Management of Students. Journal of College Counselors, 2, 78-80.

$\mathrm{Xu}$, Y. (2019a). Theory on the Management of College Students Based on the Background of Lide Shuren. Reading and Writing (Journal of Education and Teaching), 16, 46-47.

$\mathrm{Xu}, \mathrm{Z}$. (2019b). Network Ideology Security: Strategic Tasks of Ideological and Political Work in Colleges and Universities in the New Situation. Journal of Shangqiu Vocational and Technical College, 18, 1-4.

Xuan, Z. (2019). Research on the Construction of Mainstream Ideological Discourse. School Party Building and Ideological Education, 23, 88-90. 